\title{
ACE inhibitor-induced angioedema of the intestine: Case report, incidence, pathophysiology, diagnosis and management
}

\author{
Gavin Oudit MSc MD, Nigel Girgrah MD FRCPC, Johane Allard MD FRCPC
}

G Oudit, N Girgrah, J Allard. ACE inhibitor-induced angioedema of the intestine: Case report, incidence, pathophysiology, diagnosis and management. Can J Gastroenterol $2001 ; 15(12): 827-832$. A case report of fosinopril-induced angioedema of the intestine with a chronic course accompanied by multiple acute exacerbations is described. Angiotensinconverting enzyme (ACE) inhibitor-induced angioedema of the intestine (AIAI) occurs in a minority of patients taking an ACE inhibitor. The clinical presentation encompasses acute abdominal symptoms, pronounced bowel edema and ascites with occasional facial and/or oropharyngeal swelling. AIAI is diagnosed based on the temporal relationship between the symptomatic presentation and drug use, absence of alternative diagnoses including other causes of angioedema, and the prompt resolution of symptoms upon discontinuation of the ACE inhibitor. Prompt radiological investigation (abdominal computerized tomography and/or ultrasound) is critical in making an early diagnosis and in preventing unnecessary surgical intervention. There is a female predominance of AIAI, which may reflect the interaction of estradiol with the various pathways involved in the pathophysiology of AIAI. Management of AIAI consists mainly of conservative measures and discontinuation of the ACE inhibitor. Angiotensin II receptor antagonists should not be considered as appropriate alternatives. Awareness and knowledge of AIAI are important because of the increasing use of ACE inhibitors, current delays in making the diagnosis, obvious management strategies once the diagnosis is made and the dysutility of alternative diagnoses, which may lead to considerable morbidity. AIAI must be considered in patients taking ACE inhibitors who develop gastrointestinal complaints irrespective of the duration of the therapy.

Key Words: Abdominal pain; Angioedema; Angiotensin-converting enzyme (ACE) inhibitor; Sex

Oedème angioneurotique de l'intestin et inhibiteurs de l'ECA : exposé de cas, incidence, physiopathologie, diagnostic et traitement

RÉSUMÉ : Voici un exposé de cas d'œè̀me angioneurotique chronique de l'intestin provoqué par le fosinopril et émaillé de nombreux épisodes d'exacerbation. Les inhibiteurs de l'enzyme de conversion de l'angiotensine (ECA) entraînent, chez une minorité de patients, un œdème angioneurotique de l'intestin (OAI). Le tableau clinique comprend des symptômes abdominaux aigus, un œdème marqué de l'intestin, de l'ascite et parfois une tuméfaction de la face ou de l'oropharynx. Le diagnostic

voir page suivante

Division of Gastroenterology, Department of Medicine, Toronto General Hospital, University Health Network, University of Toronto, Toronto, Ontario

Correspondence: Dr J Allard, Division of Gastroenterology, Department of Medicine, Toronto General Hospital, University Health Network, EN 9, Room 217 A, 200 Elizabeth Street, Toronto, Ontario M5G 2C4. Telephone 416-340-5159, fax 416-348-0065,

email johane.allard@utoronto.ca

Received for publication June 8, 2000. Accepted October 31, 2000 
d'OAI repose sur la relation temporelle entre l'apparition des symptômes et la prise du médicament, l'absence d'autres diagnostics possibles, y compris d'autres causes d'œedème angioneurotique, ainsi que sur la disparition rapide des symptômes après l'interruption de l'inhibiteur de l'ECA. La pose rapide du diagnostic appelle une exploration radiologique immédiate (tomodensitométrie abdominale ou échographie). L'OAI touche plus souvent les femmes, ce qui peut être l'indice d'une interaction de l'oestradiol avec les différentes voies de la physiopathologie de l'OAI. Le traitement consiste principalement en des mesures conservatrices et en l'arrêt du médicament. Les inhibiteurs des récepteurs de l'angiotensine II ne conviennent pas comme médicaments de rechange. Il est important d'être sensibilisé à l'existence de l'OAI et d'en connaitre les manifestations en raison de l'utilisation plus répandue des inhibiteurs de l'ECA, des délais actuels pour la pose du diagnostic, des stratégies évidentes de traitement et de l'inutilité d'autres diagnostics, d'où aggravation sérieuse de la morbidité. L'OAI doit être envisagé chez les patients qui prennent des inhibiteurs de l'ECA et qui se plaignent de troubles gastro-intestinaux, indépendamment de la durée du traitement.
$\mathrm{T}$ he proven benefits of angiotensin-converting enzyme (ACE) inhibitors in the management of congestive heart failure, hypertension, and diabetes mellitus-related cardiovascular and renal complications have led to a tremendous increase in their use in the past decade. As such, adverse effects of ACE inhibitors are increasingly being recognized and reported (1-6). Cough, the most common side effect of ACE inhibitor therapy, occurs in 5\% to $20 \%$ of patients and is more common in women than in men (1). Angioedema, a potentially life-threatening complication, occurs in $0.1 \%$ to $0.2 \%$ of patients receiving $\mathrm{ACE}$ inhibitors, with $60 \%$ of cases presenting within the first week (1-6). The incidence of angioedema is fivefold higher in black people, but is independent of age and dose of ACE inhibitor $(3,5)$. The typical presentation of angioedema involves swelling of the facial and/or oropharyngeal tissue with occasional dermatological manifestations.

Delay in diagnosis and the continuing use of ACE inhibitors are associated with recurrent angioedema and serious morbidity (4-8). The percentage of patients with reported cases of delayed onset of angioedema, defined as the first appearance of symptoms after six months and up to six years, is continually increasing over time. For example, in 1992, 1996 and 1998, 8.9\%, 28\% and 54\% of patients, respectively, presented with delayed angioedema as the first mode of clinical presentation (8). The two major gastrointestinal manifestations of ACE inhibitor adverse effects are angioedema of the intestine (4,9-19) and acute pancreatitis $(20,21)$. The connection between the more common forms of angioedema and gastrointestinal involvement was recognized by Osler (22), who stated that "associated with the oedema there is almost invariably gastrointestinal disturbance: colic, nausea, vomiting, and sometimes diarrhea".

Although there have been several recent case reports of ACE inhibitor-induced angioedema of the intestine (AIAI), the primary gastroenterology literature has failed to incorporate this important adverse drug reaction of $\mathrm{ACE}$ inhibitor as a cause of a distinct gastroenterological disorder. As such, the purpose of this review article is to illustrate a case of AIAI, identify and summarize all case reports of AIAI, and provide an approach to AIAI with an emphasis on incidence, pathophysiology, diagnosis and management. A computerized search of MEDLINE for English-language articles using the PubMed search engine was conducted using the following MeSH (medical subject heading) terms: 'angioedema', 'ACE inhibitors', 'intestine' and 'abdominal pain' in various combinations. Relevant articles were also identified through a manual review of references.

\section{CASE PRESENTATION}

A 37-year old woman with a prior history of gastrointestinal disorders presented to the emergency department with acute onset of painful abdominal cramps, nausea, and several episodes of vomiting and watery diarrhea. Her past medical history was remarkable for essential hypertension and chronic gastrointestinal complaints, with several visits to the emergency department. Two days before presentation, the dose of fosinopril (ACE inhibitor) was increased from $10 \mathrm{mg}$ once daily to $30 \mathrm{mg}$ once daily. She was also taking an oral contraceptive. She had no known allergies to drugs or environmental agents, and her travel history was negative. There was no family history for any diseases. The patient was afebrile, and no facial or oropharyngeal swelling was noted. Mild diffuse abdominal tenderness with bulging flanks and flank dullness were present.

Investigations revealed a normal complete blood cell count, serum electrolytes, serum amylase, liver enzymes, liver function test results, coagulation and renal function test results. Viral serology (hepatitis B, C, cytomegalovirus and Epstein-Barr) was negative, and no toxins or infectious organisms were isolated from stool specimens. Ascitic fluid had a clear yellow appearance with an exudative pattern; microbiology cultures, including acid-fast bacilli, were unrevealing. Autoimmune serology including erythrocyte sedimentation rate, rheumatoid factor, antinuclear antibodies and antineutrophil cytoplasmic antibodies were negative. Complement (C3 and C4) and C1 esterase inhibitor (C1-INH) levels were normal. Urinalysis results were normal with a negative urobilinogen screen. Upper endoscopy and colonoscopy results were normal. Ileal and colonoscopic biopsy specimens had normal histological appearance, and cultures were negative for any bacteria, viruses and acid-fast bacilli. A computerized tomography (CT) scan (with intravenous and oral contrast) and ultrasound of the abdomen (with Doppler interrogation) were done (Figure 1). Blood flow in the portal, superior mesenteric and hepatic veins, and the hepatic/biliary system was normal. The pancreas appeared normal and there was no evidence of lymphadenopathy. AIAI was diagnosed based on the criteria listed in Table 1; fosinopril was discontinued, and her symptoms abated in $24 \mathrm{~h}$. Follow-up over a oneyear period revealed no recurrence of symptoms. 

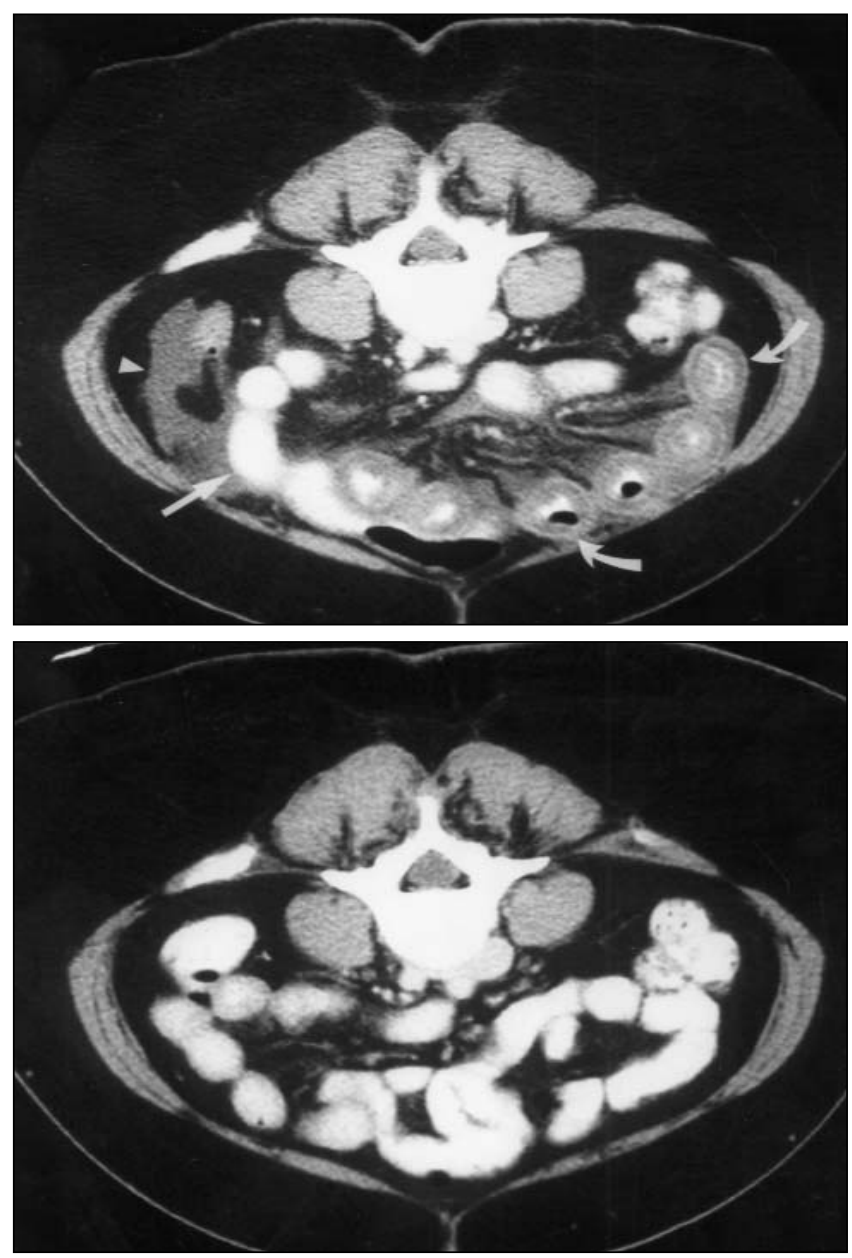

Figure 1) Spiral computerized tomography of the abdomen (with intravenous and oral contrast). Top During an acute attack of angiotensinconverting enzyme (ACE) inhibitor-induced angioedema of the intestine demonstrating circumferential transmural thickening of ileal loops producing a target-like lesion typical of intestinal edema (curved arrows), ascites (arrowhead) with normal proximal small bowel loops (straight arrow). Bottom Three weeks after cessation of the ACE inhibitor (fosinopril) illustrating complete resolution of the previous abnormal findings. Reproduced with permission from reference 9

\section{INCIDENCE OF AIAI}

Despite the well-documented incidence of cutaneous and/or facial/oropharyngeal angioedema (see above), no study has systematically examined the incidence of AIAI in patients taking ACE inhibitors. Several lines of evidence suggest that angioedema of the intestine is underdiagnosed, and more recent data have highlighted the clinical importance of AIAI. First, acute nonspecific abdominal pain (NSAP) accounts for $13 \%$ to $40 \%$ of all emergency surgical admissions and is associated with an extensive series of investigations (23). Despite further investigations at substantial cost, about one-third of all patients with acute abdominal pain leave the hospital without a final diagnosis. Although drug-induced angioedema may be partly responsible for acute NSAP, most studies fail to report a detailed drug history (23).

Second, angioedema occurred in $0.4 \%$ of the 4645 patients who received ramipril in the Heart Outcomes
TABLE 1

Diagnostic criteria for angiotensin-converting enzyme (ACE) inhibitor-induced angioedema of the intestine

Use of an ACE inhibitor (irrespective of dose and duration of use)

Nonspecific abdominal complaint(s) with the presence of bowel

edema (with or without ascites)

Resolution of symptoms and radiological changes following

discontinuation of ACE inhibitor

Absence of alternative diagnoses

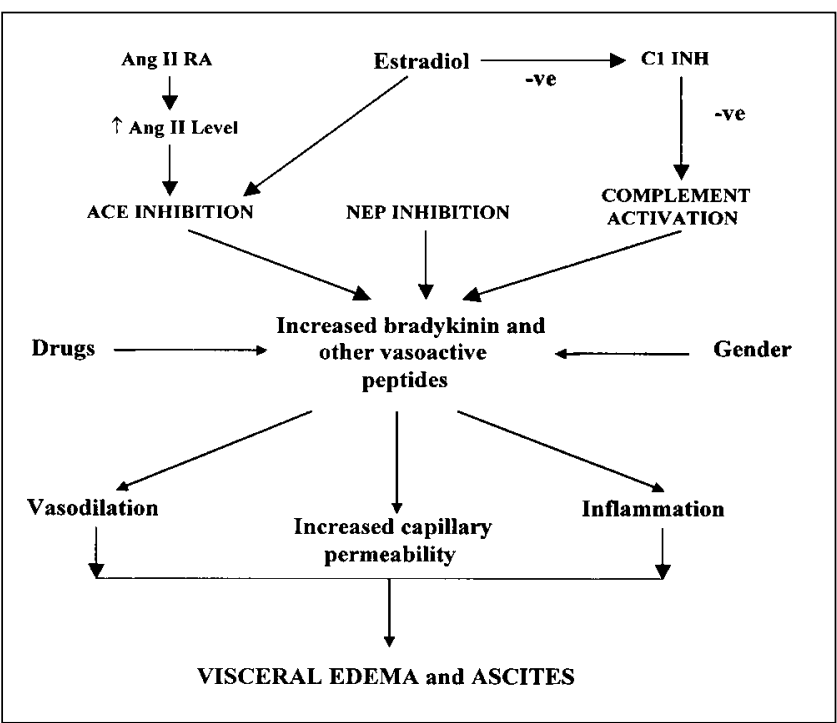

Figure 2) Pathophysiological mechanisms involved in angiotensin-converting enzyme (ACE) inhibitor-induced angioedema of the intestine. Ang II Angiotensin II; Ang II RA Ang II receptor antagonist; C1 INH C1 esterase inhibitor; -ve Negative inhibition; NEP Neutral endopeptidase inhibition

Prevention Evaluation (HOPE) study (compared with $0.2 \%$ in the placebo group) (24). Given the high level of ACE inhibitor usage worldwide, with approximately 35 to 40 million patients exposed to ACE inhibitors, the morbidity and/or mortality from AIAI could be considerable (25). Third, the recent use of a combined ACE and neutral endopeptidase (NEP) inhibitor, omapatrilat, in patients with heart failure has lead to an increased incidence of angioedema with a concomitant $35 \%$ incidence of gastrointestinal adverse effects, including diarrhea and abdominal pain (26). Increased angioedema is not unexpected because both enzyme systems inactivate bradykinin, an important mediator of angioedema (Figure 2). Given this important adverse reaction, there has been a temporary withdrawal of the new drug application for omapatrilat (25).

\section{PATHOPHYSIOLOGY}

The precipitation of angioedema involves an interaction of environmental triggers in genetically susceptible individuals. The pathophysiological mechanisms involve an interaction between immunological factors, complement pathways and various peptidergic and aminergic byproducts 
TABLE 2

Summary of all case reports describing angiotensin-converting enzyme (ACE) inhibitor-induced angioedema of the intestine

\begin{tabular}{|c|c|c|c|c|c|c|}
\hline Case & $\begin{array}{c}\text { Age } \\
\text { (years) }\end{array}$ & Sex & $\begin{array}{l}\text { ACE inhibitor } \\
\text { (dose, } \mathrm{mg} \text { ) }\end{array}$ & $\begin{array}{c}\text { Treatment } \\
\text { duration }\end{array}$ & Presentation & Author (reference), year \\
\hline 1 & 41 & $\mathrm{~F}$ & Enalapril (5) & $12 \mathrm{~h}$ & AAS, bowel edema & Farraye et al (19), 1988 \\
\hline 2 & 48 & $\mathrm{~F}$ & Captopril (37.5) & 3 years & AAS, FOS, ascites & Matsumura et al (18), 1993 \\
\hline 3 & 51 & $\mathrm{~F}$ & Enalapril (5) & 9 weeks & AAS, FOS & Jacobs et al (17), 1994 \\
\hline 4 & 29 & $\mathrm{~F}$ & Lisinopril (20) & 10 months & AAS, ascites & Guy et al (16), 1994 \\
\hline 5 & 59 & $\mathrm{~F}$ & Enalapril (NR) & 7 years & AAS, bowel edema & Mullins et al (15), 1996 \\
\hline 6 & 58 & $\mathrm{~F}$ & Lisinopril (NR) & Several days & AAS, FOS, bowel edema & Gregory and Davis (14), 1996 \\
\hline 7 & 41 & $\mathrm{~F}$ & Lisinopril (5) & 2 days & AAS, ascites, bowel edema & Abdelmalek and Douglas (13), 1997 \\
\hline 8 & 61 & M & Captopril (200) & 5 years & AAS, FOS & Smoger and Sayed (12), 1998 \\
\hline 9 & 46 & $\mathrm{~F}$ & Enalapril (2.5) & 5 years & AAS, FOS, bowel edema & Jardine et al (11),1999 \\
\hline 10 & 72 & $\mathrm{~F}$ & Lisinopril (5-20) & 5 months & AAS, bowel edema & Chase et al (10), 2000 \\
\hline 11 & 67 & $\mathrm{~F}$ & Fosinopril (NR) & 3 years & AAS, FOS, ascites, bowel edema & Byrne et al (4), 2000 \\
\hline 12 & 41 & $\mathrm{~F}$ & Lisinopril (20) & 2 years & AAS, ascites, bowel edema & Byrne et al (4), 2000 \\
\hline 13 & 37 & $\mathrm{~F}$ & Fosinopril (30) & 6 years & AAS, ascites, bowel edema & Oudit et al (9), 2000 \\
\hline
\end{tabular}

AAS Acute abdominal symptoms (nausea, vomiting, abdominal pain/distension, diarrhea); F Female; FOS Facial and/or oropharyngeal swelling; M Male; NR Not reported

(1,4-6,25,27-29). AIAI has been described with a range of ACE inhibitors, which suggests that the pathophysiology is closely related to their pharmacological mechanisms of action rather than to idiosyncratic drug reactions (Table 2). ACE and NEP inhibition are associated with a reduction in the metabolism of bradykinin and substance P, leading to accumulation of these peptides in the plasma and/or tissues $(27,30)$. By using a sensitive assay, plasma bradykinin levels were shown to have a greater than 10-fold increase in patients with hereditary and ACE-inhibitor induced angioedema (27). The final common pathway culminates in angioedema and exudative ascites due to uncontrolled vasodilation, increased capillary permeability and extravasation of fluid from the visceral vasculature (Figure 2). Histological findings from biopsy of the intestine include normal findings (9) and submucosal edema $(11,15)$ with intact villous architecture and the absence of cellular infiltrate. Angiotensin II receptor antagonists cause an increase in plasma angiotensin II levels, which may lead to a negative feedback inhibition of ACE activity, thus predisposing individuals to developing angioedema.

Female predominance has been documented in the incidence of ACE inhibitor-induced cough and angioedema $(1,2,6)$. This is consistent with our findings involving AIAI, where 12 of the 13 patients (greater than 90\%) were women, with most being in the pre- or perimenopausal period (Table 2). Estradiol suppresses ACE activity because women taking hormonal replacement therapy (HRT) have a proportionately greater reduction in ACE activity (31) (Figure 2). As such, the addition of an ACE inhibitor may cause a proportionately greater increase in bradykinin levels. In addition, women taking estrogen have a lower level of C1-INH (32). Lower levels of C1-INH are associated with an increased risk of ACE inhibitor-induced angioedema (33). Indeed, estrogen use via contraceptive or HRT is contraindicated in women with hereditary angioedema
(HA) (29). As such, women during the pre- and perimenopausal periods, as well as those taking estrogen-containing preparations, may be more prone to ACE inhibitor-induced angioedema because the reduced inhibitor function of C1-INH (complement pathway) may predispose the tissues to the increased bradykinin levels (ACE pathway) following ACE inhibition.

\section{DIAGNOSTIC APPROACH}

A total of 13 case reports describing AIAI have revealed several characteristic features of the disease (Table 1). Patients often have recurrent episodes of abdominal complaints and are sometimes given an alternative diagnosis with occasional surgical intervention (4,9-19). The time of diagnosis varied from a few hours to seven years following the initiation of ACE inhibitor, with over $75 \%$ of patients (10 of 13 patients) having a delayed diagnosis (two months or longer), and was independent of the dose of ACE inhibitor (9-19). This was likely due to a delay in presentation and/or diagnosis. Patients reported a chronic use of ACE inhibitors associated with recurrent gastrointestinal symptoms and multiple episodes of acute exacerbations. Gastrointestinal symptoms in patients taking ACE that cannot be explained by other more common causes should prompt physicians to consider AIAI, irrespective of the duration of therapy. In addition, several patients had prior episodes of angioedema involving the face and/or oropharynx. As such, a diagnosis of ACE inhibitor-induced angioedema of the face and/or oropharynx does not preclude the possibility of AIAI.

Radiological studies (contrast-enhanced CT and/or ultrasonography) are instrumental in documenting the location and extent of bowel edema and ascites and their resolution. The characteristic radiological findings of AIAI are similar to those of HA (34-41) and include segmental thickened bowel wall (small and/or large intestine), nar- 
rowed lumen, and prominent and thickened valvulae conniventes, often with the presence of ascites (4,9-19) (Figure 1). An extensive history and series of investigations are essential to rule out allergic, C1-INH deficiency (hereditary and acquired), inflammatory (including infectious), vascular (including lymphatic blockage and hemorrhage), and other miscellaneous causes of ascites and bowel edema. Documented causes of angioedema of the intestine include the use of ACE inhibitors (AIAI) (4,9-19), dual inhibitors of ACE and neutral endopeptidase (eg, omapatrilat) $(30,42)$, allergic reactions to drugs, food and radiographic contrast agents $(30,42)$, HA with and without the use of ACE inhibitor (34-40) and malignancy-associated paraneoplastic manifestation $(40,41)$.

Routine evaluations should include hematological, biochemical, microbiological and radiological investigations as well as ascitic fluid analysis. Inadequate inhibition of the first component of human complement (C1-INH) gives rise to HA and an acquired form of angioedema (43). HA is commonly diagnosed when patients present with recurrent gastrointestinal symptoms and bowel edema (34-40). As such, complement (C3, $\mathrm{C} 4$ and $\left.\mathrm{CH}_{50}\right), \mathrm{Clq}$ and $\mathrm{C} 1$-INH levels should always be measured with samples taken during the symptomatic period to increase the diagnostic yield (41). Moreover, the diagnosis of HA, irrespective of the use of ACE inhibitor, has important and unique management strategies $(34-41,43)$. When radiological studies reveal large bowel involvement, a colonoscopy with mucosal biopsy is beneficial in excluding diagnoses of an inflammatory and/or vascular origin.

AIAI was diagnosed based on the temporal relationship between the use of an ACE inhibitor, absence of alternative diagnoses and the resolution of symptoms upon discontinuation of the ACE inhibitor (Table 2). A follow-up assessment(s) with a repeat radiological procedure (abdominal CT or ultrasound) is of critical importance in the postdischarge period to confirm a complete resolution of the ascites and bowel wall edema and to substantiate the diagnosis. A rechallenge with an ACE inhibitor should not be attempted.

\section{MANAGEMENT OF AIAI}

Although approximately half of the patients with AIAI had prior presentations involving facial and/or oropharyngeal swelling, no patient had concomitant airway compromise (4,9-19). However, a cautionary approach must be taken, and respiratory status must be closely monitored in these patients. Patients should continue to receive nothing by mouth, and be given supportive care and adequate fluid resuscitation, and the ACE inhibitor should be discontinued. The possible development of hypovolemia and small bowel obstruction must be closely monitored in the acute setting. However, in all nine cases described, symptoms resolved within 24 to $48 \mathrm{~h}$ without the need for specific medical therapy. In particular, there is no role for antihistamine or corticosteroids during the acute symptomatic period. The reversible nature of the disorder is clearly revealed by the prompt resolution of symptoms once the diagnosis is made and the offending drug discontinued.

Follow-up care is crucial to establish a continued resolution of symptoms and to confirm the diagnosis. The long term management issues involve a life-long abstinence from ACE inhibitors and the use of an alternative agent(s). Angiotensin II receptor antagonists (ARA) are not suitable substitutes for ACE inhibitors in patients diagnosed with AIAI. Angioedema has also been reported with ARA, albeit with a lower incidence and/or severity, irrespective of a prior history of ACE inhibitor-induced angioedema (6). For example, $32 \%$ of patients with reported ARA-induced angioedema had experienced a prior episode of angioedema attributed to ACE inhibitor therapy (6). ARA, via an indirect pathway, may lead to inhibition of endogenous ACE activity (Figure 2). Unless the patient has documented C1INH deficiency, the use of synthetic androgens (danazol or stanozolol) is not indicated. We recommend that a safety wrist bracelet be worn so that health professionals can be forewarned of the underlying medical condition.

\section{CONCLUSIONS}

Given the high prevalence of nonspecific abdominal pain in our population, drug-related causes for abdominal complaints must be carefully sought. Angioedema involving the gastrointestinal system should be considered in patients taking ACE inhibitors who present with acute and/or chronic abdominal symptoms, irrespective of the duration of therapy. AIAI is an important diagnosis because the dysutility of a delayed and/or missed diagnosis is considerable, and treatment options are simplistic and straightforward. Prompt radiological investigation(s) during the symptomatic phase is a key component to making the diagnosis. AIAI is completely reversible following the discontinuation of the offending ACE inhibitor. HA must be ruled out as an important comorbidity. ARAs should not be used as substitutes for the ACE inhibitors.

\section{REFERENCES}

1. Israili ZH, Hall WD. Cough and angioneurotic edema associated with angiotensin-converting enzyme inhibitor therapy. A review of the literature and pathophysiology. Ann Intern Med 1992;117:234-42.

2. Gabb GM, Wing LMH, Ryan P, Hutchinson KA. Epidemiological study of angioedema and ACE inhibitors. Aust NZ J Med 1996;26:777-82.

3. Brown NJ, Ray WA, Snowden M, Griffin MR. Black Americans have an increased rate of angiotensin converting enzyme inhibitor associated angioedema. Clin Pharmacol Ther 1996;60:8-13.

4. Byrne TJ, Douglas D, Landis ME, Heppell J. Isolated visceral angioedema: and underdiagnosed complication of ACE inhibitors? Mayo Clin Proc 2000; 75:1201-4.

5. Vleeming W, van Amsterdam JGC, Sticker BHC, de Wildt DJ. ACE inhibitor-induced angioedema. Incidence, prevention and management. Drug Saf 1998;18:171-88.

6. Warner KK, Visconti JA, Tschampel MM. Angiotensin II receptor blockers in patients with ACE inhibitor-induced angioedema. Ann Pharmacother 2000;34:526-8.

7. Brown NJ, Snowden M, Griffin MR. Recurrent angiotensinconverting enzyme inhibitor-associated angioedema. JAMA 1997;278:232-3.

8. Wernze H. ACE inhibitor-induced angioedema: remarkable new perspectives for intensive care/emergency medicine. 
Anasthesiol Intensivmed Notfallmed Schmerzther 1998;33:637-41.

9. Oudit GY, Dill-Mackay MJ, Allard JP. Image of the month (fosinopril-induced angioedema of the intestine). Gastroenterology 2000;119:1190,1424.

10. Chase MP, Fiarman GS, Scholz FJ, MacDermott RP. Angioedema of the small bowel due to an angiotensin-converting enzyme inhibitor. J Clin Gastroenterol 2000;31:254-7.

11. Jardine DL, Anderson JC, McClintock AD. Delayed diagnosis of recurrent visceral angio-oedema secondary to ACE inhibitor therapy. Aust NZ J Med 1999;29:377-8.

12. Smoger SH, Sayed MA. Simultaneous mucosal and small bowel angioedema due to captopril. South Med J 1998;91:1060-3.

13. Abdelmalek MF, Douglas DD. Lisinopril-induced isolated visceral angioedema. Dig Dis Sci 1997;42:847-50.

14. Gregory KWP, Davis RC. Angioedema of the intestine. N Engl J Med 1996;335:1641.

15. Mullins RJ, Shanahan TM, Dobson RT. Visceral angioedema related to treatment with an ACE inhibitor. Med J Aust 1996;165:319-21.

16. Guy C, Cathebras P, Rousset H. Suspected angioedema of abdominal viscera. Ann Intern Med 1994;121:900.

17. Jacobs RL, Hoberman LJ, Goldstein HM. Angioedema of the small bowel caused by an angiotensin-converting enzyme inhibitor. Am J Gastroenterol 1994;89:127-8.

18. Matsumura M, Haruki K, Kajinami K, Takada T. Angioedema likely related to angiotensin converting enzyme inhibitors. Intern Med 1993;32:424-6.

19. Farraye FA, Peppercorn MA, Steer ML, Joffe N, Rees M. Acute small-bowel mucosal edema following enalapril use. JAMA 1988;259:3131.

20. Maringhini A, Termini A, Patti R, Ciambra M, Biffarella P, Pagliaro L. Enalapril-associated acute pancreatitis: recurrence after rechallenge. Am J Gastroenterol 1997;92:166-7.

21. Arjomand H, Kemp DG. Quinapril and pancreatitis. Am J Gastroenterol 1999;94:290-1.

22. Osler W. Hereditary angio-neurotic oedema. Am J Med Sci 1888;95:362-7.

23. Poulin EC, Schlachta CM, Mamazza J. Early laparoscopy to help diagnose acute non-specific abdominal pain. Lancet 2000;355:861-2.

24. Yusuf S, Sleight P, Pogue J, Bosch J, Davies R, Dagenais G. Effects of an angiotensin-converting-enzyme inhibitor, ramipril, on cardiovascular events in high-risk patients. The Heart Outcomes Prevention Evaluation Study Investigators. N Engl J Med 2000;342:145-53.

25. Messerli FH, Nussberger J. Vasopeptidase inhibition and angiooedema. Lancet 2000;356:608-9.

26. Rouleau JL, Pfeffer MA, Stewart DJ, et al. Comparison of vasopeptidase inhibitor, omapatrilat, and lisinopril on exercise tolerance and morbidity in patients with heart failure: IMPRESS randomized trial. Lancet. 2000;356:615-20.
27. Nussberger J, Cugno M, Amstutz C, et al. Plasma bradykinin in angioedema. Lancet 1998;351:1693-7.

28. Branco-Ferreira M, Pedro E, Barbosa MA, Carlos AG. Ascites in hereditary angioedema. Allergy 1998;53:543-5.

29. Agostoni A, Cicardi M. Hereditary and acquired C1-inhibitor deficiency: biological and clinical characteristics in 235 patients. Medicine 1992;71:206-15.

30. Zanjanian MH. The intestine in allergic diseases. Ann Allergy 1976;37:208-18

31. Proudler AJ, Ahmed AIH, Crook D, Fogelman I, Rymer JM, Stevenson JC. Hormone replacement therapy and serum angiotensin-converting-enzyme activity in postmenopausal women. Lancet 1995;346:89-90.

32. Gordon EM, Ratnoff OD, Saito H, Donaldson VH, Pensky J, Jones PK. Rapid fibrinolysis, augmented Hagemen factor (factor XII) titers, and decreased $\mathrm{C} 1$ esterase inhibitor titers in women taking oral contraceptives. J Lab Clin Med 1980;96:762-9.

33. Sigler C, Annis K, Cooper K, Haber H, Van deCarr S. Examination of baseline levels of carboxypeptidases $\mathrm{N}$ and complement components as potential predictors of angioedema associated with the use of an angiotensin-converting enzyme inhibitor. Arch Dermatol 1997;133:972-5.

34. Wong RCW, Phan TG, Adelstein S, Basten A. Image of the month. Gastroenterology 1999;116:514.

35. Ebo DG, Stevens WJ, Bosmans JL. An adverse reaction to angiotensin-converting enzyme inhibitors in a patient with neglected C1 esterase deficiency. J Allergy Clin Immunol 1997;99:425-6.

36. Shah TJ, Knowles WO, McGeady SJ. Hereditary angioedema with recurrent abdominal pain and ascites. J Allergy Clin Immunol 1995;96:259-61.

37. Talavera A, Larraona J, Ramos J, et al. Hereditary angioedema: an infrequent cause of abdominal pain with ascites. Am J Gastroenterol 1995;90:471-4.

38. Weinstock LB, Kothari T, Sharma RN, Rosenfeld SI. Recurrent abdominal pain as the sole manifestation of hereditary angioedema in multiple family members. Gastroenterology 1987;93:1116-8.

39. Warin RP, Higgs ER. Acute and recurrent abdominal pain due to hereditary angioedema. BMJ 1982;284:1912.

40. Eck SL, Morse JH, Janssen DA, Emerson SG, Markovitz DM. Angioedema presenting as chronic gastrointestinal symptoms. Am J Gastroenterol 1993;88:436-9.

41. Ciaccia D, Brazer SR, Baker ME. Acquired C1 esterase inhibitor deficiency causing intestinal angioedema: CT appearance. AJR Am J Roentgenol 1993;161:1215-6.

42. Polger M, Kuhlman JE, Hansen FC, Fishman EK. Computed tomography of angioedema of small bowel due to reaction to radiographic contrast medium. J Comput Assist Tomogr 1988;12:1044-6.

43. Markovic SN, Inwards DJ, Frigas EA, Phyliky RP. Acquired C1 esterase inhibitor deficiency. Ann Intern Med 2000;132:144-50. 


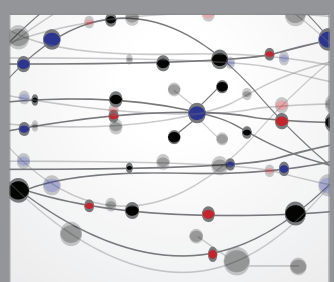

The Scientific World Journal
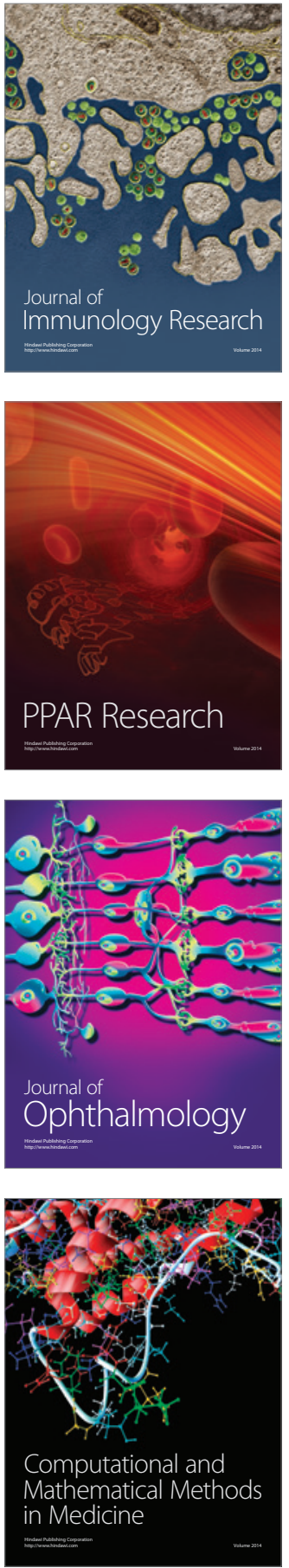

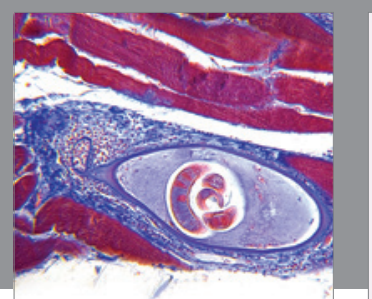

Gastroenterology Research and Practice

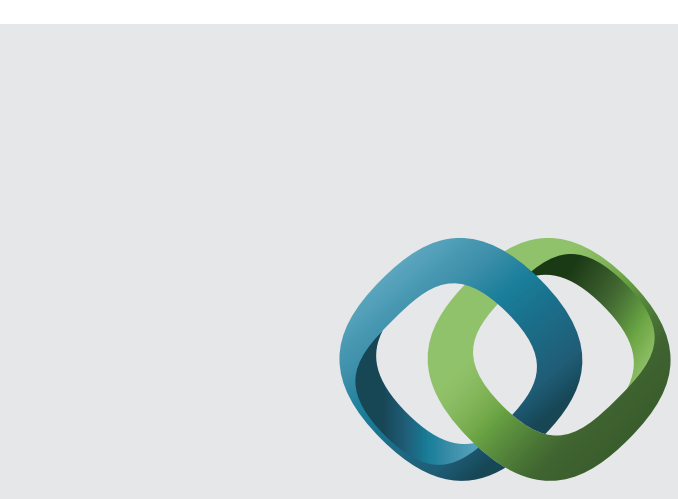

\section{Hindawi}

Submit your manuscripts at

http://www.hindawi.com
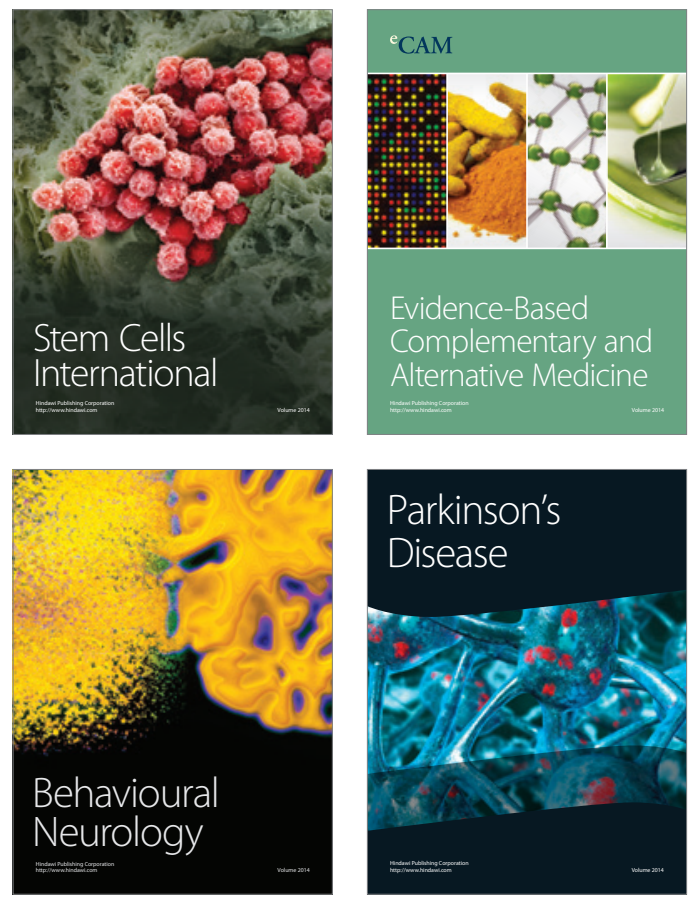
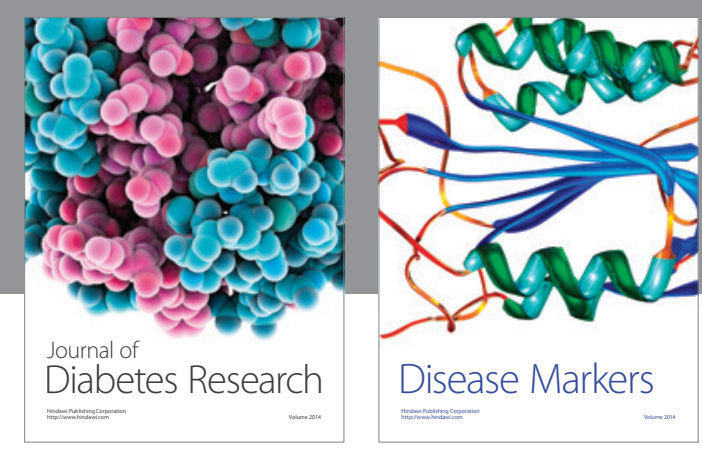

Disease Markers
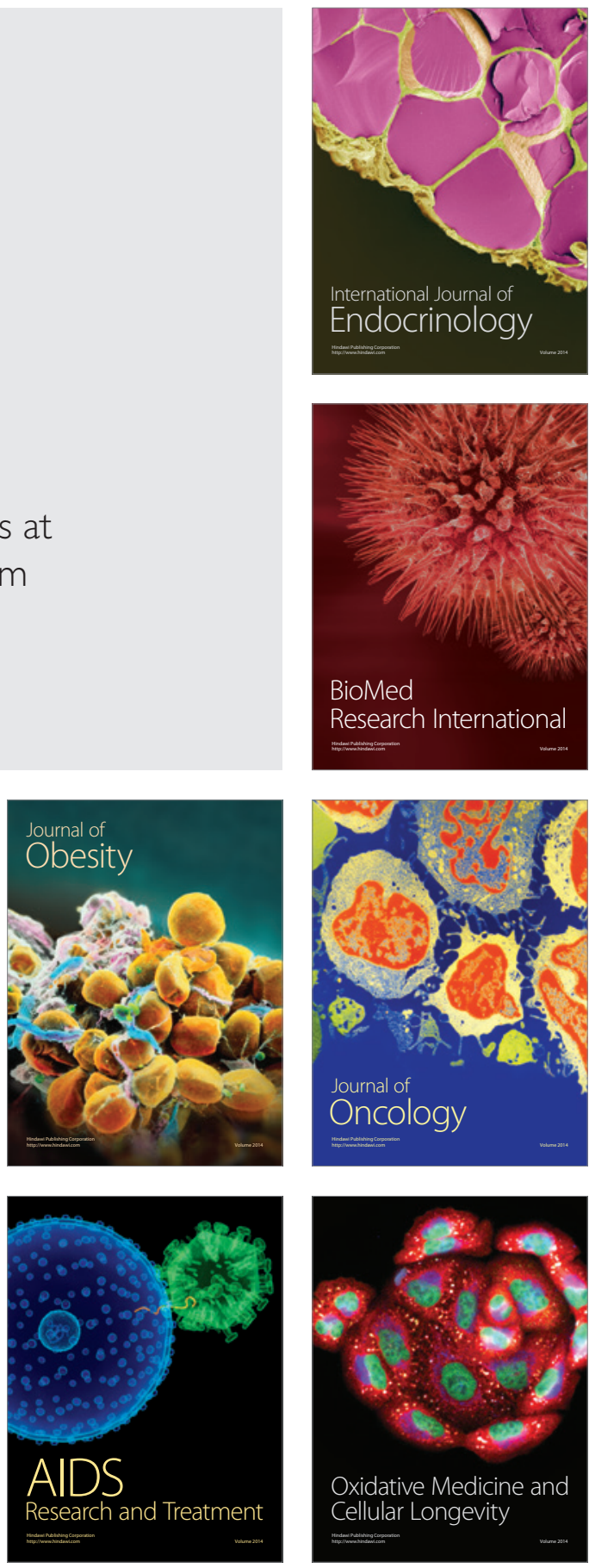